Article

\title{
Plastic Film Mulching Sustains High Maize (Zea mays L.) Grain Yield and Maintains Soil Water Balance in Semiarid Environment
}

\author{
Ming Li ${ }^{1}$, Kaiping Zhang ${ }^{1}$, Ibrahim M. Eldoma ${ }^{2}$, Yanjie Fang ${ }^{3, *}$ and Feng Zhang ${ }^{1,4,5, *}$ \\ 1 State Key Laboratory of Grassland Agro-Ecosystems, Institute of Arid Agroecology, School of Life Sciences, \\ Lanzhou University, Lanzhou 730000, China; lim15@lzu.edu.cn (M.L.); zhangkp19@lzu.edu.cn (K.Z.) \\ 2 Faculty of Agriculture, University of Zalingei, Zalingei 79371, Sudan; eldoma111@yahoo.com \\ 3 Institute of Dryland Farming, Gansu Academy of Agricultural Sciences, Key Laboratory of High Water \\ Utilization on Dryland of Gansu Province, Lanzhou 730070, China \\ 4 Key Laboratory of High Water Utilization on Dryland of Gansu Province, Lanzhou 730000, China \\ 5 Research Center od Low Carbon Economy, Research Base of Humanities and Social Sciences of Fujian \\ Institutions of Higher Learning, School of Economics and Management, Sanming University, \\ Sanming 365004, China \\ * $\quad$ Correspondence: fangyj82@126.com (Y.F.); zhangfeng@lzu.edu.cn (F.Z.); Tel.: +86-139-1927-4617 (F.Z.)
}

Received: 15 March 2020; Accepted: 18 April 2020; Published: 23 April 2020

\begin{abstract}
Ridge-furrow cultivation with plastic film mulching has been widely used for many years to increase crop yields in semiarid regions. The long-term effects of plastic mulching on crop yield and soil water balance need to be seriously considered to assess the sustainability of this widely used field management technique. A seven-year maize field experiment was conducted during 2012-2018 to estimate the yield sustainability and soil water balance with two treatments-mulching (yes; no) and nitrogen fertilization (yes; no). This resulted in the following four groups-no film mulching, no $\mathrm{N}$ application (M0N0); film mulching, no N application (M1N0); no film mulching, $\mathrm{N}$ application (M0N1); film mulching and $\mathrm{N}$ application (M1N1). Our results show that plastic mulching significantly increased maize yield. A combination of mulching and nitrogen application had the highest sustainability yield index (SYI) of 0.75, which was higher than the other three treatments, with SYI values of $0.31,0.33$, and 0.39 , respectively. Plastic film mulching increased soil water content and water storage in both the sowing and harvesting periods and did not cause the formation of dry soil layers. Precipitation storage efficiency (PSE) in the nongrowing season played a key role in maintaining the soil water balance and it was positively affected by plastic film mulching. Our research indicates that plastic mulching and $\mathrm{N}$ application could maintain maize yield sustainability and the soil water balance of agriculture in semiarid regions. In addition, we highlight the importance of nongrowing season precipitation, and thus, we suggest that mulching the field land with plastic film throughout the whole year should be adopted by farmers to store more precipitation, which is important to crop growth.
\end{abstract}

Keywords: ridge-furrow cultivation; sustainability yield index; soil water balance

\section{Introduction}

Ridge-furrow cultivation with full plastic film mulching (RFM) field management has been proven to be an innovative and effective method to promote crop production in semiarid areas of the Loess Plateau, China [1-3]. The Loess Plateau accounts for about $6.7 \%$ of China's total land area, and this region is of the utmost importance for food production in China [1]. However, agriculture in the Loess Plateau region faces the challenges associated with climate change, such as extreme rainfall [4]. 
In recent decades, RFM systems have been widely used and rapidly expanded [5]. With the development of the plastic film mulching technique, there have been a lot of studies focusing on this form of field management. A large amount of experiments have been conducted to study the effects of plastic film mulching on semiarid agriculture, such as its effect on soil temperature [6,7], crop productivity [3,8,9], soil water status [10-12], and soil nutrients [13-15]. Through so many previous studies, the physiological mechanisms involved are well known. However, most previous investigations are field experiments conducted for about 2-4 years [5]. Compared with short-term experiments, long-term studies have more advantages in agricultural sciences, as long-term experiments can provide better opportunities to study crop yield dynamics over time and estimate agricultural sustainability $[16,17]$. Therefore, long-term field studies need to be carried out to investigate the persistent influence of RFM on agriculture in semiarid regions. Furthermore, it is necessary to establish a comprehensive evaluation index of agricultural sustainability and provide suggestions for sustainable development. It has been reported many times that the sustainability yield index (SYI) is an important parameter to measure the sustainability of agricultural systems [18,19]. SYI is derived from actual yields over long periods and its value ranges from 0 to 1 . A higher SYI suggests a better yield sustainability, while a low SYI indicates unsustainable management practices $[20,21]$.

The annual mean precipitation across the Loess Plateau is $250-550 \mathrm{~mm}$ and the potential evapotranspiration is $900-1980 \mathrm{~mm}$. As evapotranspiration is several times the precipitation, soil water deficit has become an important issue in this area [12]. The shortage of water is the major factor that limits crop production $[5,22]$. Furthermore, the distribution of precipitation in this region is uneven during the cropping year, and uneven rainfall causes stress during drought-sensitive development states, which further limit crop productivity $[8,12,23,24]$. Therefore, the first problem to be solved concerns making full use of the insufficient water by optimally using precipitation and inhibiting unproductive evaporation [12,25]. The RFM system maximizes the collection of rainwater into furrows and allows it to penetrate deeper into the soil, meanwhile reducing soil water loss by impeding evaporation from the soil surface [26]; as a result, more water is stored in the soil and is used for crop growth, dramatically increasing maize grain yield. It is obvious that crop productivity is positively affected by RFM, while at the same time, the increased vegetation growth feeds back to affect the soil water balance. Because high crop production indicates high soil water consumption, the question of whether the RFM system overuses agricultural soil water and leads to the formation of dry soil layers is tightly related to the water cycle and future vegetation growth [27]; these issues remain unknown.

It has been widely reported that soil water dynamics affect the growth and yield of crops $[9,10,28]$. However, most previous studies focused on the water status during the crop growing season, and comprehensive analyses of soil water dynamics during the whole year, especially in the nongrowing season and in the long-term, are lacking [12,29]. Water storage at the beginning of the growing season is a key component of the total water supply for crop growth. The amount determines whether the crop can get enough water for emergence and avoid yield failure, especially for rainfed agriculture. Thus, increasing water collection in the nongrowing season is important. Precipitation storage efficiency (PSE) in the nongrowing season, i.e., the net change in soil water with respect to total precipitation during the fallow season, has been proved to be an excellent index to measure the degree of water recharge and plays an important role in maintaining the soil water balance [30]. However, the effects of the RFM system on PSE have rarely been studied.

A seven-year field experiment was implemented with the following objectives-(1) to investigate the long-term effect of RFM on maize (Zea mays L.) yield and soil water dynamics; and (2) to evaluate the sustainability of RFM from the point of view of yield stability and soil water balance in semiarid environments. 


\section{Materials and Methods}

\subsection{Experimental Site and Design}

The experiment was established at the Semiarid Ecosystem Research Station $\left(36.03^{\circ} \mathrm{N}, 104.42^{\circ} \mathrm{E}\right)$ run by Lanzhou University in Yuzhong County, Gansu Province, China. A brief description of this experimental site is presented in Table 1.

Table 1. Brief description of the experimental site.

\begin{tabular}{cccc}
\hline \multicolumn{4}{c}{ Study Site Properties } \\
\hline Geographic Information & \multicolumn{3}{c}{ Soil Information } \\
\hline Longitude & $104.42^{\circ} \mathrm{E}$ & Soil type & Heima soil \\
Latitude & $36.03^{\circ} \mathrm{N}$ & Clay $(<0.002 \mathrm{~mm})$ & $37 \%$ \\
Altitude & $2318 \mathrm{~m}$ & Silt $(0.002-0.05 \mathrm{~mm})$ & $59 \%$ \\
Mean air temperature & $6.8{ }^{\circ} \mathrm{C}$ & Sand $(0.05-2.0 \mathrm{~mm})$ & $4 \%$ \\
Mean accumulated temperature & $2310{ }^{\circ} \mathrm{C}$ & Water content at field capacity & $22.9 \%$ \\
Annual precipitation & $318 \mathrm{~mm}$ & Permanent wilting point & $6.2 \%$ \\
\hline
\end{tabular}

From 2012 to 2018, a randomized block design sown with maize was used in the field experiment. The experiment included two treatments-mulching (yes; no) and nitrogen fertilization (yes; no). The resulting four groups are as follows-(1) cultivation without film mulching and $\mathrm{N}$ application (M0N0); (2) cultivation with film mulching but without N application (M1N0); (3) cultivation without film mulching but with $\mathrm{N}$ application (M0N1); (4) cultivation with film mulching and $\mathrm{N}$ application (M1N1). Each treatment had three replications. In mid-April for each year, the field was ploughed to a depth of $30 \mathrm{~cm}$ by a rotary cultivator; twelve plots were set in total, and each plot was $10 \mathrm{~m}$ long and $10 \mathrm{~m}$ wide, with the space between plots being $0.5 \mathrm{~m}$ wide. In the $100 \mathrm{~m}^{2}$ plot, ridges and furrows were artificially built at height of $15 \mathrm{~cm}$; the width of the ridge was $55 \mathrm{~cm}$ (Figure 1). For the plastic film mulching treatment, plastic film was fully mulched on the ridge and furrow surface. The plastic film was colorless, transparent, and was $0.008 \mathrm{~mm}$ thick, and $1.2 \mathrm{~m}$ wide. After mulching the soil, several holes by which the rainwater could reach the soil surface and sink into soil were made. For the $\mathrm{N}$ application treatment, $150 \mathrm{~kg} \mathrm{~N} \mathrm{ha}^{-1}$ was applied before ploughing the field. After mulching the plastic film for about one week, maize was planted artificially at an interval of $40 \mathrm{~cm}$ in each row with a density of 47,500 plants ha $^{-1}$.
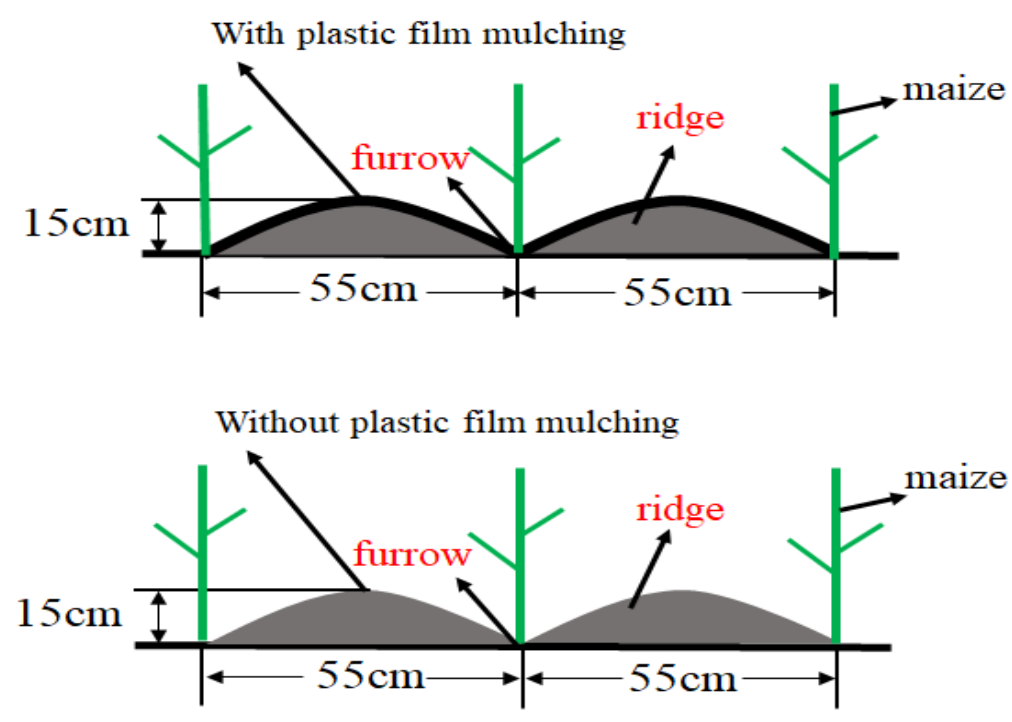

Figure 1. Ridge-furrow with/without full plastic film mulching diagram. 
Maize was harvested in early October, and after harvesting in each year, the maize residue was removed, and the plastic film was left on the field surface for the whole year.

\subsection{Maize Production Measurement}

Maize grain yield was measured in the center of each plot in the harvest period at the end of September or beginning of October in 2012-2018 in a subsampling area which was $22 \mathrm{~m}^{2}$ (4 m in width $\times 5.5 \mathrm{~m}$ in length). Corn cobs were harvested artificially and then air-dried in an open place for about 1 month until they could be threshed. The maize grain after threshing was dried by oven at $65^{\circ} \mathrm{C}$ to a constant weight to calculate the dry yield.

\subsection{Soil Water Measurement}

Daily precipitation during the experimental period was recorded by the HOBO T/RH U23-002 data logger (Onset Computer Corporation, Bourne, MA, USA). Soil samples for gravimetrical water content measurement were sampled at $20 \mathrm{~cm}$ intervals to a depth of $200 \mathrm{~cm}$ at the sowing and harvesting periods of each year; the sampling dates are shown in Table 2. At each sampling point, soil samples were taken randomly and centrally between two plants in the furrow using a soil drill (metal cylinder, diameter $=5 \mathrm{~cm}$ ) in the plot center and oven-dried at $105^{\circ} \mathrm{C}$ to a constant weight to calculate the gravimetric water content. The bulk density of each soil layer was measured using the cutting ring method $[8,31]$ and was used to determine soil water storage.

Table 2. Date of soil sampling before and after the growing season in each year and the sampled soil depth.

\begin{tabular}{cccccccc}
\hline \multirow{2}{*}{ Items } & \multicolumn{7}{c}{ Cropping Year } \\
\cline { 2 - 8 } & $\mathbf{2 0 1 2}$ & $\mathbf{2 0 1 3}$ & $\mathbf{2 0 1 4}$ & $\mathbf{2 0 1 5}$ & $\mathbf{2 0 1 6}$ & $\mathbf{2 0 1 7}$ & $\mathbf{2 0 1 8}$ \\
\hline $\begin{array}{c}\text { Date of sampling before } \\
\text { growing season }\end{array}$ & 9 Apr & 2 May & 28 Apr & 23 Apr & 21 Apr & 18 Apr & 23 Apr \\
$\begin{array}{c}\text { Date of sampling after } \\
\text { growing season }\end{array}$ & 21 Sep & 22 Oct & 17 Oct & 10 Oct & 23 Oct & 19 Oct & 16 Oct \\
Soil depth of sampling $(\mathrm{cm})$ & 200 & 200 & 200 & 200 & 200 & 200 & 200 \\
\hline
\end{tabular}

\subsection{Data Analysis}

Sustainability yield index (SYI) was calculated as in Equation (1):

$$
\mathrm{SYI}=\frac{\mathrm{GYmean}-\mathrm{S} n-1}{\mathrm{GY} \max }
$$

where $\mathrm{GY}_{\text {mean }}$ is the mean yield of the experimental years, $\mathrm{S}_{n-1}$ is the standard deviation, and $\mathrm{GY}_{\max }$ is the maximum yield. Soil water storage (SWS, $\mathrm{mm}$ ) was calculated as in Equation (2):

$$
\mathrm{SWS}=\mathrm{SWC} \times \mathrm{SBD} \times \mathrm{H},
$$

where SBD is the soil bulk density $\left(\mathrm{g} \mathrm{cm}^{-3}\right)$, SWC is the soil water content $(\%)$, and $\mathrm{H}$ is the depth of the soil layer $(\mathrm{cm})$. Water use efficiency (WUE, $\mathrm{kg} \mathrm{ha}^{-1} \mathrm{~mm}^{-1}$ ) was calculated using Equation (3):

$$
\mathrm{WUE}=\frac{\mathrm{GY}}{\mathrm{ET}} \times 100 \%,
$$


where GY $\left(\mathrm{kg} \mathrm{ha}^{-1}\right)$ is the grain yield, and ET is evapotranspiration in the maize growing season. In the area where the present study was carried out, there is no irrigation and underground water. The upper $200 \mathrm{~cm}$ layers can store almost all the precipitation because of their good water-holding capacity, and so, little drainage occurs below $200 \mathrm{~cm}[7,8]$. Therefore, ET was calculated using Equation (4):

$$
\mathrm{ET}=\mathrm{P}+\triangle \mathrm{SWS},
$$

where $\mathrm{P}$ is the total precipitation during the growing season, and $\triangle$ SWS is the difference in SWS $(0-200 \mathrm{~cm})$ between the beginning and the end of growing season. The PSE was calculated [30] using Equation (5):

$$
\mathrm{PSE}=\frac{\triangle \mathrm{SWS}}{\mathrm{P}} \times 100 \%,
$$

where $\triangle$ SWS $(\mathrm{mm})$ is the soil water storage difference between the ending SWS and the beginning SWS in the following growth season, and $\mathrm{P}$ is the precipitation between the beginning and ending soil water measurements.

Two-way analysis of variance (ANOVA) and least significant difference $(p<0.05)$ were used to test the effects of plastic film mulching and $\mathrm{N}$ application on grain yield, water use efficiency (WUE), SWS, PSE, and water recharge in each year. All analyses were performed using GenStat 18th edition (VSN International Ltd., Rothamsted, UK) and graphs were created using Origin 9.2 (Origin Lab Origin Pro 2017, Northampton, MA, USA). A linear fitting function was used to validate the relationships between water recharge, PSE, and precipitation in the nongrowing season.

\section{Results}

\subsection{Precipitation during the Experimental Period from 2012 to 2018}

Annual precipitation varied greatly between years and was 378.0, 356.6, 421.1, 294.0, 284.8, 350.3, and $458.8 \mathrm{~mm}$ for 2012-2018, respectively (Figure 2). Compared with long-term average precipitation (318.0 mm) during 1986-2018, the average precipitation during the experimental period was $45.4 \mathrm{~mm}$ higher. Between the 7 experimental years, year 2015 and 2016 were relatively dry and 2012-2014, 2017, and 2018 were relatively wet. In each growing season from 2012-2018, the precipitation was 328.8, 329.1, 400.1, 237.0, 248.8, 320.1, and $405.6 \mathrm{~mm}$. Precipitation was uneven between months and most of this occurred in July-September (Figure 2). 


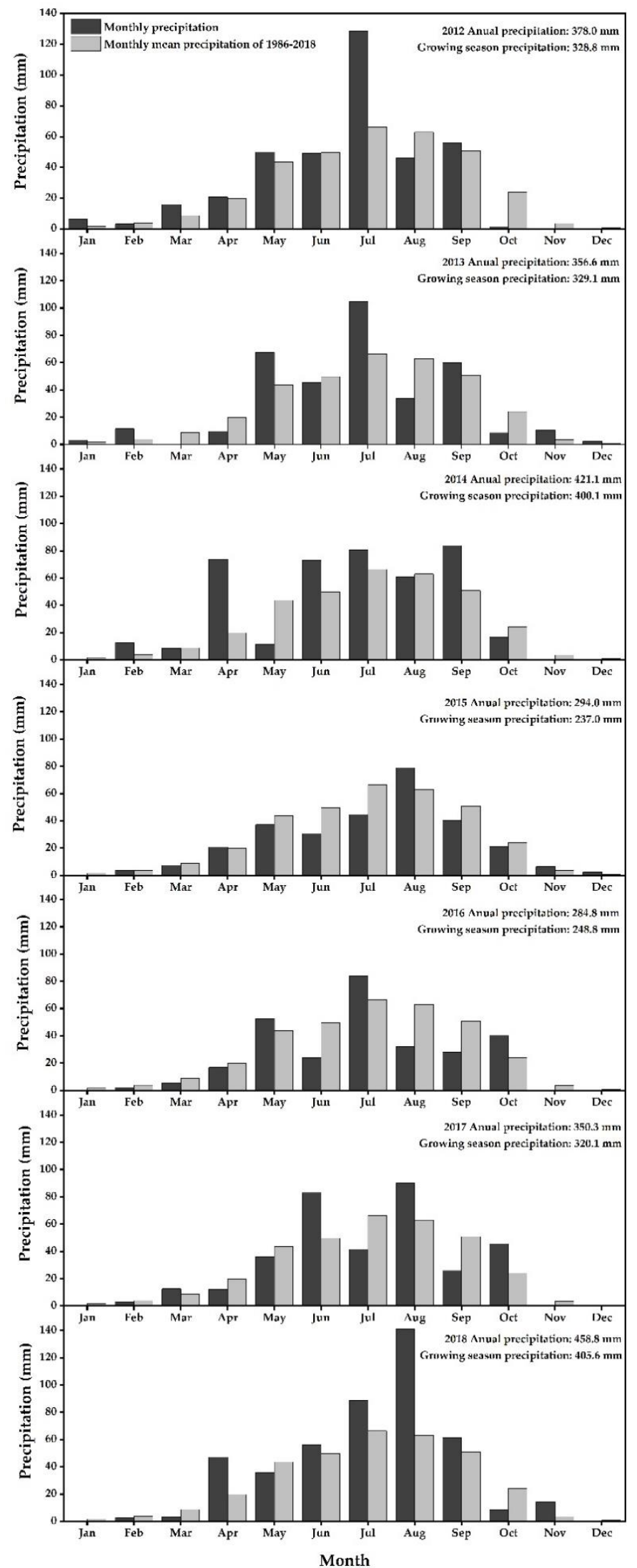

Figure 2. Annual growing season and monthly precipitation of the experimental years and of the past 33 years (1986-2018) at the study site. 


\subsection{Maize Grain Yield and Sustainability Yield Index (SYI)}

In all 7 years, plastic film mulching increased maize grain yield significantly both with and without $\mathrm{N}$ addition (Table 3). N application had no effect on grain yield in the years 2012, 2013, and 2014, while it promoted maize grain yield in the years 2015, 2016, 2017, and 2018. There was no significant interaction between plastic mulching and $\mathrm{N}$ application in the first three years, but the interaction between them in the last four years was significant. Maize grain yield varied with the experiment year. A combination of mulching and $\mathrm{N}$ application dramatically increased the sustainability yield index of the 7 years. The M1N1 treatment had the highest SYI, which was 0.74 , meanwhile, in the M0N0, M1N0, and M0N1 treatments, the SYIs were $0.31,0.33$, and 0.39, respectively (Table 3 ).

Table 3. Maize grain yield with ANOVA results during experimental years, and the sustainability yield index.

\begin{tabular}{ccccccccc}
\hline Treatments & \multicolumn{7}{c}{ Maize Grain Yield $\mathbf{( k g ~ h a - 1 )}$} & \multicolumn{2}{c}{ SYI } \\
\hline & $\mathbf{2 0 1 2}$ & $\mathbf{2 0 1 3}$ & $\mathbf{2 0 1 4}$ & $\mathbf{2 0 1 5}$ & $\mathbf{2 0 1 6}$ & $\mathbf{2 0 1 7}$ & $\mathbf{2 0 1 8}$ \\
\hline M0N0 & $1926 \mathrm{a}$ & $1591 \mathrm{a}$ & $1480 \mathrm{a}$ & $695 \mathrm{a}$ & $1092 \mathrm{a}$ & $489 \mathrm{a}$ & $529 \mathrm{a}$ & 0.31 \\
M1N0 & $6894 \mathrm{~b}$ & $4893 \mathrm{~b}$ & $5427 \mathrm{~b}$ & $3079 \mathrm{c}$ & $3151 \mathrm{~b}$ & $2482 \mathrm{c}$ & $2329 \mathrm{~b}$ & 0.33 \\
M0N1 & $1978 \mathrm{a}$ & $1544 \mathrm{a}$ & $1773 \mathrm{a}$ & $1255 \mathrm{~b}$ & $986 \mathrm{a}$ & $742 \mathrm{~b}$ & $2512 \mathrm{~b}$ & 0.39 \\
M1N1 & $7001 \mathrm{~b}$ & $5162 \mathrm{~b}$ & $5502 \mathrm{~b}$ & $6797 \mathrm{~d}$ & $5730 \mathrm{c}$ & $6367 \mathrm{~d}$ & $5176 \mathrm{~d}$ & 0.74 \\
\hline M & $* * *$ & $* * *$ & $* * *$ & $* * *$ & $* * *$ & $* * *$ & $* * *$ & $* * * *$ \\
N & n.s & n.s & n.s & $* * *$ & $* * *$ & $* * *$ & $* * *$ & $* *$ \\
M N N & n.s & n.s & n.s & $* * *$ & $* *$ & $* *$ & \\
\hline
\end{tabular}

Note: $\mathrm{M}-$ plastic film mulching; $\mathrm{N}-\mathrm{N}$ application; $\mathrm{SYI}-$ sustainability yield index. The different lowercase letters indicate significant difference at $p<0.05$; “***” indicates significant difference at $p<0.001$; "n.s" indicates there is no significant difference.

\subsection{Soil Profile Water Status and Storage}

The soil water dynamics results during the experimental period from 2012 to 2018 are shown in Figure 3. Plastic film mulching increased soil water content in both the sowing and harvesting periods. In the sowing period of each year, soil water content of the two treatments with mulching (M1N0, M1N1) were higher than the other two treatments without mulching (M0N0, M0N1). In addition, in the harvesting period, M1N0 had much more water than the other three groups. Furthermore, $\mathrm{N}$ application reduced the water content because it promoted maize growth and then increased water consumption.

Soil water storage varied with the year and was positively affected by plastic film mulching (Figure 4). The difference in water storage between mulching treatments and nonmulching treatments in the sowing period was more than that in the harvesting period. There was no significant difference of water storage between the two treatments with plastic mulching (M1N0, M1N1) in the years 2012, 2013, and 2014, no matter whether it was in the sowing or harvesting period. However, from 2015, the water storage of the M1N0 group was higher than that of the M1N1 group, except at the end of the experiment (2018-H). In general, the water storage of two treatments without mulching (M0N0, M0N1) was not different; only in 2012-H, 2013-S, 2018-H, did M0N1 have higher water storage than M0N0, while in 2015-H and 2017-H, the water storage of M0N0 was more than M0N1 (Figure 4). 


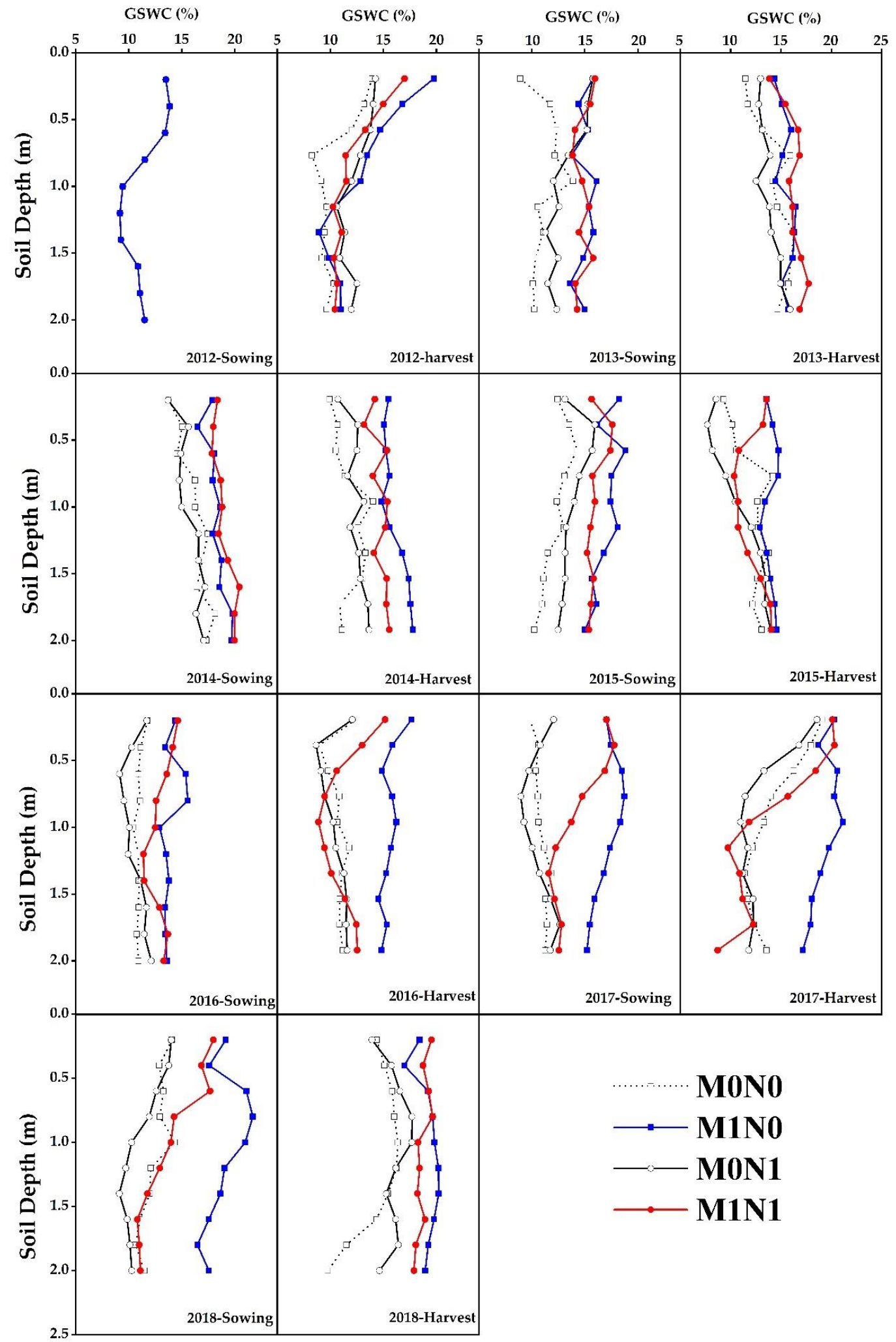

Figure 3. Soil profile water content at a depth of 0-200 $\mathrm{cm}$ during the experimental period. M0N0—cultivation without film mulching and N application; M1N0—cultivation with film mulching but without $\mathrm{N}$ application; M0N1—cultivation without film mulching but with $\mathrm{N}$ application; M1N1 — cultivation with film mulching and N application; GSWC—gravimetric soil water content. 


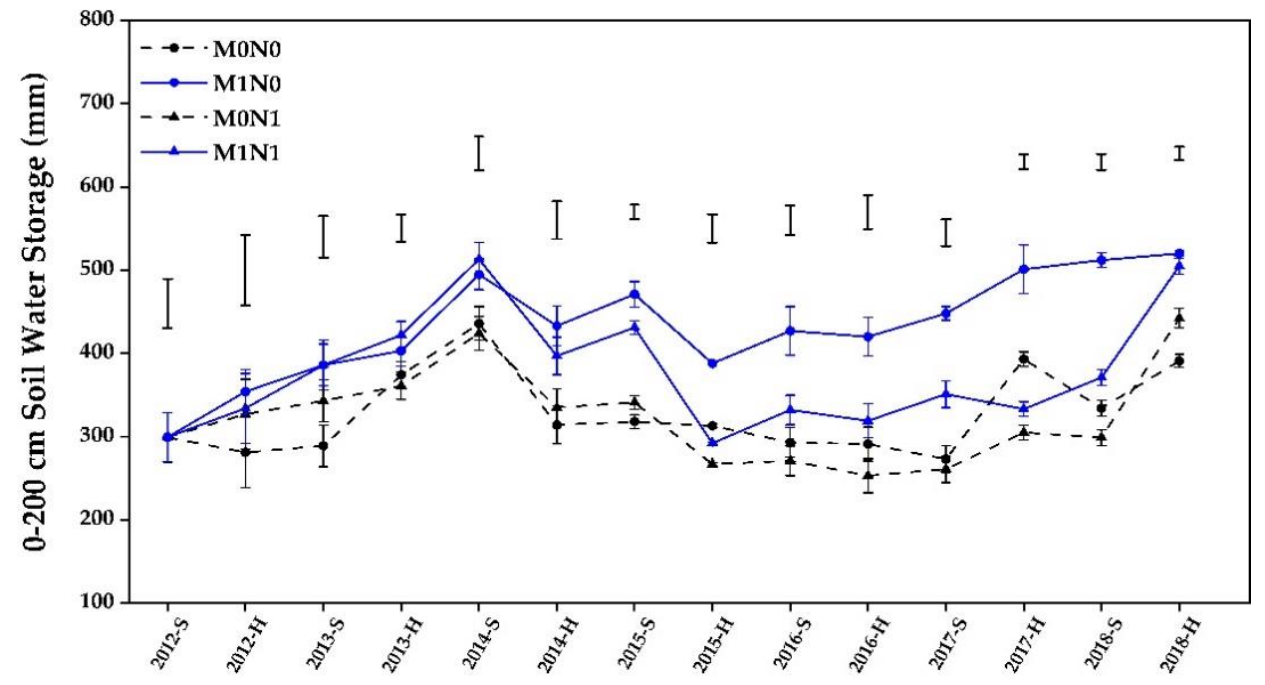

Figure 4. Soil water storage at a depth of $0-200 \mathrm{~cm}$ during the experimental period. M0N0-cultivation without film mulching and $\mathrm{N}$ application; M1N0—cultivation with film mulching but without $\mathrm{N}$ application; M0N1—cultivation without film mulching but with $\mathrm{N}$ application; M1N1—cultivation with film mulching and $\mathrm{N}$ application. Vertical bars above the curves are least significant difference (LSD) $(p=0.05)$ of significant differences; vertical bars of each curve are the standard deviation.

\subsection{Water Use Efficiency in the Growing Season and Precipitation Storage Efficiency in the Nongrowing Season}

In all the 7 years, the water use efficiency of maize in the treatments with plastic mulching was significantly higher than the treatments without plastic mulching (Figure 5). The effect of nitrogen application on WUE varied with the year except in 2012. In 2013 and 2014, the WUE of M1N0 was higher than M1N1, while in 2015-2018, the WUE of M1N1 was higher than M1N0. There was no difference between the two treatments without film mulching except in 2018, in which the WUE of M0N1 was higher than M0N0 and M1N0.

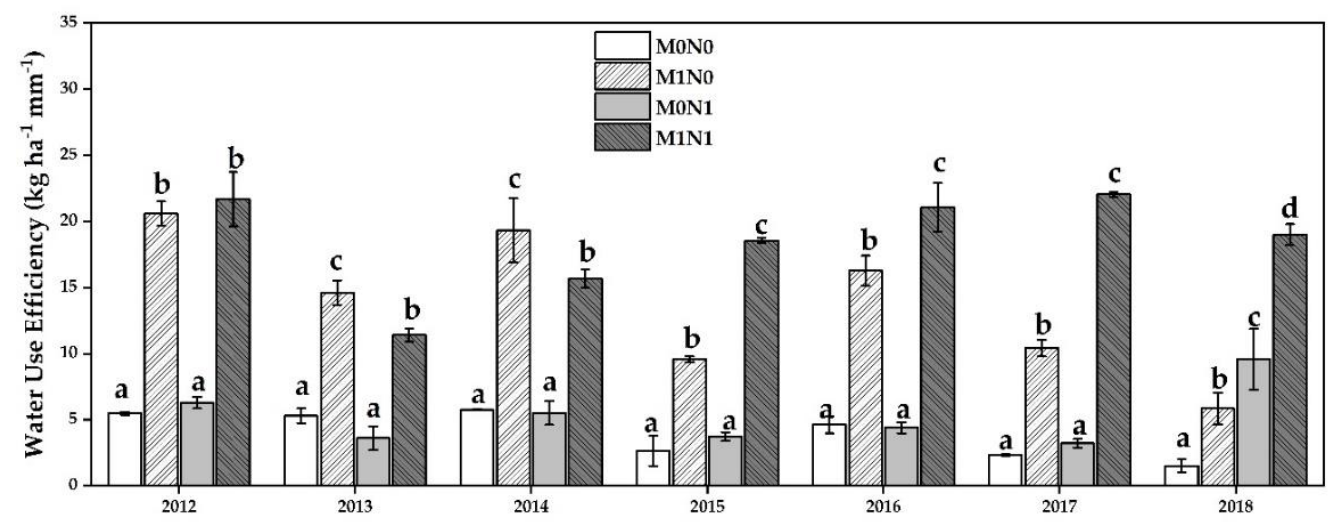

Figure 5. Water use efficiency of each treatment from 2012-2018. M0N0-cultivation without film mulching and $\mathrm{N}$ application; M1N0 — cultivation with film mulching but without $\mathrm{N}$ application; M0N1—cultivation without film mulching but with N application; M1N1—cultivation with film mulching and $\mathrm{N}$ application. The different lowercase letters indicate significant difference at $p<0.05$.

The precipitation values in the six nongrowing seasons were 59.8, 111.6, 49.0,54.0, 42.0, and $46.8 \mathrm{~mm}$, respectively (Table 4). Water recharge and the precipitation storage efficiency (PSE) were both positively affected by plastic film mulching in each nongrowing season; water recharge and PSE of M1N0 and M1N1 were significantly higher than that of M0N0 and M0N1. Meanwhile, water recharge and PSE varied with the year as the precipitation was different between the six nongrowing seasons. 
Table 4. Precipitation, water recharge, and precipitation storage efficiency (PSE) in the nongrowing season.

\begin{tabular}{|c|c|c|c|c|c|c|}
\hline Year & Treatments & $\begin{array}{c}\text { SWBN } \\
(\mathrm{mm})\end{array}$ & $\begin{array}{l}\text { Precipitation } \\
(\mathrm{mm})\end{array}$ & $\begin{array}{l}\text { SWEN } \\
(\mathrm{mm})\end{array}$ & $\begin{array}{l}\text { Water Recharge } \\
\text { (mm) }\end{array}$ & PSE (\%) \\
\hline \multirow{4}{*}{ 2012-2013 } & MONO & 281 & \multirow{4}{*}{59.8} & 289 & 8.3 & $13.9 \mathrm{a}$ \\
\hline & M1No & 354 & & 386 & 31.6 & $52.8 \mathrm{~b}$ \\
\hline & M0N1 & 327 & & 343 & 16.0 & $27.5 \mathrm{a}$ \\
\hline & M1N1 & 334 & & 386 & 52.0 & $85.5 \mathrm{c}$ \\
\hline \multirow{4}{*}{ 2013-2014 } & MONO & 374 & \multirow{4}{*}{111.6} & 436 & 62.3 & $55.8 \mathrm{a}$ \\
\hline & M1N0 & 403 & & 495 & 91.6 & $82.1 \mathrm{~b}$ \\
\hline & M0N1 & 361 & & 424 & 63.2 & $56.6 \mathrm{a}$ \\
\hline & M1N1 & 422 & & 513 & 91.0 & $81.5 \mathrm{~b}$ \\
\hline \multirow{4}{*}{ 2014-2015 } & MONO & 314 & \multirow{4}{*}{49.0} & 318 & 4.3 & $8.8 \mathrm{a}$ \\
\hline & M1N0 & 433 & & 471 & 38.0 & $77.6 \mathrm{~b}$ \\
\hline & M0N1 & 335 & & 341 & 5.5 & $11.2 \mathrm{a}$ \\
\hline & M1N1 & 397 & & 431 & 33.8 & $68.9 \mathrm{~b}$ \\
\hline \multirow{4}{*}{ 2015-2016 } & MONO & 313 & \multirow{4}{*}{54.0} & 293 & -20.0 & $-37.0 \mathrm{a}$ \\
\hline & M1N0 & 388 & & 427 & 39.2 & $72.2 c$ \\
\hline & M0N1 & 267 & & 271 & 3.5 & $7.4 \mathrm{~b}$ \\
\hline & M1N1 & 292 & & 332 & 40.8 & $74.1 \mathrm{c}$ \\
\hline \multirow{4}{*}{ 2016-2017 } & MONO & 291 & \multirow{4}{*}{42.0} & 273 & -18.0 & $-42.9 \mathrm{a}$ \\
\hline & M1N0 & 420 & & 448 & 28.0 & $66.7 \mathrm{c}$ \\
\hline & M0N1 & 253 & & 261 & 7.8 & $19.0 \mathrm{~b}$ \\
\hline & M1N1 & 319 & & 351 & 31.7 & $76.2 \mathrm{c}$ \\
\hline \multirow{4}{*}{ 2017-2018 } & MONO & 393 & \multirow{4}{*}{46.8} & 334 & -49.0 & $-126 a$ \\
\hline & M1N0 & 501 & & 512 & 10.9 & $23.5 c$ \\
\hline & M0N1 & 305 & & 299 & -6.7 & $-12.8 \mathrm{~b}$ \\
\hline & M1N1 & 333 & & 371 & 38.6 & $81.2 \mathrm{~d}$ \\
\hline
\end{tabular}

Note: SWBN—soil water storage at the beginning of nongrowing season; SWEN—soil water storage at the ending of nongrowing season. PSE-precipitation storage efficiency. The different lowercase letters indicate significant difference at $p<0.05$

\section{Discussion}

\subsection{Effect of Long-Term Plastic Film Mulching on Maize Yield}

In this study, we assessed two factors-plastic film mulching and $\mathrm{N}$ application. In each of the seven years of the experiment, it was proved that full plastic film mulching could promote maize grain yield, and this is consistent with previous studies in the Loess Plateau region [7,32-34]. The availability of water is the key to successful dryland agriculture, and a high level of WUE is particularly important $[14,35,36]$; the high levels of WUE seen in the present study confirmed these findings. Nitrogen fertilization was another important factor that can affect crop production. In our study, we found that from 2015, N application increased maize grain yield and the interaction of RFM and $\mathrm{N}$ addition was significant; while in the years 2012, 2013, and 2014, nitrogen fertilization had no effect on maize yield (Table 3). Furthermore, the yield of corn grain in the M0N0 and M1N0 groups decreased by three-fold, while in the M0N1 group, grain yield did not change over the 7 years. These phenomena might be the result of the basic nitrogen content in the soil. Maize was planted on the experimental site by local farmers for 6 years, who added nitrogen and organic fertilizer each year, so the nitrogen data needed to be further analyzed to include the total nitrogen and $\mathrm{NO}_{3}{ }^{-}-\mathrm{N}$ and $\mathrm{NH}_{4}{ }^{+}-\mathrm{N}$ content in the soil. In semiarid areas, water shortage is the first limiting factor, so compared with $\mathrm{N}$ addition, the application of plastic film has a greater impact on the maize yield in rainfed agriculture.

The maize grain yield in our study strongly varied with the cropping years, which can be explained by the different amount and distribution of precipitation. It is important to study the rainfall distribution in different phenological stages of maize, so that we can better understand the formation of maize yield. Sustainability yield index is widely used to access the effects of agricultural practices on crop yield sustainability. The value of SYI is affected by many field management factors including fertilization, types of plants, and so on. Han et al. studied the SYI of wheat and rice under eight 
different fertilization levels through an experiment over 30 years [16]. They found that fertilization could increase the SYI of both wheat and rice, and the SYI value of wheat ranged from 0.28 to 0.47 , while that of rice was higher, ranging from 0.51 to 0.70 . Li et al. compared the SYI of rice, wheat, and maize in different locations around China. They found that fertilization increased SYI, with values of $0.57,0.58$, and 0.66 for wheat, maize, and rice, respectively [37]. Moreover, they found that the SYI of maize had the largest coefficient of variation (CV).

Most previous studies focused on the effects of fertilization, while few studies have been conducted on the influence of plastic film mulching. In the present study, the SYI of maize in M0N0, M1N0, M0N1, and M1N1 treatments was $0.31,0.33,0.39$, and 0.75 , respectively. In our research, the CV of SYI was large, which implies that the sustainability yield index in semiarid environments is more sensitive to field management. Different rainfall among the cropping years was the reason why M0N0 and M0N1 had low SYIs, and the low SYI in M1N0 was due to the lack of nitrogen in the soil. We found that the M1N1 treatment had the highest SYI, more than the mean value of maize SYI (0.58) [37], which indicates that the maize yield in the M1N1 treatment was sustainable.

\subsection{Effect of Long-Term Plastic Film Mulching on Water Status}

Normally, higher agricultural production will consume more water and lead to the formation of soil desiccation layers, especially in the semiarid regions of the Loess Plateau [27]. However, in our research, the RFM system increased soil water content on average in both the sowing and harvest period. Higher agricultural production did consume more water, but at the same time, film mulching could also store more water in soil, which kept the water balance.

We know that rainfall is the only water resource for agriculture in some semiarid regions, and thus making full use of rainfall is key to increasing agricultural production. The benefits that film mulching brings to the crop growth during the growing season are accepted without controversy $[10,24,33,38]$, but few studies pay attention to the soil water during the fallow season $[25,39,40]$. The amount of soil water that has recharged during the fallow season determines whether there are sufficient water resources for crop growth in the next season. We found that soil water recharge in the nongrowing season was positively correlated $(p<0.001)$ with the total nongrowing precipitation in all the four treatments (Figure 6), and compared with the nonmulched treatments, plastic film mulching had more recharged water.

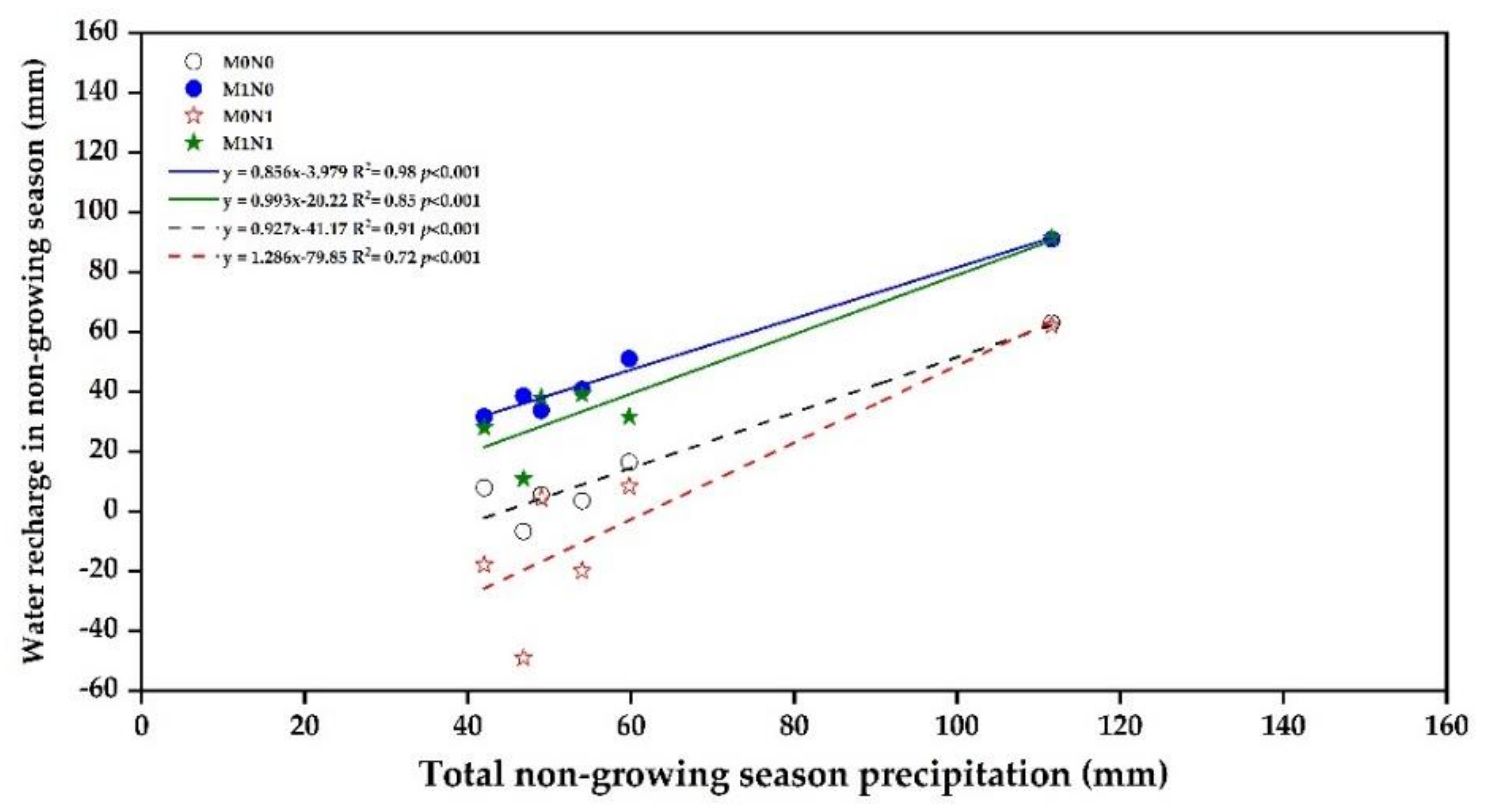

Figure 6. Linear relationship between precipitation and water recharge in the nongrowing season. 
In our study, we highlight the importance of RFM during the nongrowing season as it increased the soil water recharge. Precipitation is a natural parameter that cannot be changed by farmers. Therefore, higher precipitation storage efficiency plays a key role in the success of the RFM system. The PSE in the nongrowing season is determined by soil type, the amount and distribution of precipitation, evaporation, and the residue water left in the soil by the previous crop [41]. It can also be modified by agricultural practices such as ridge-furrowing, film mulching, and deep ploughing [12,25,42]. The soil texture, which is a given property of the native soil and does not change with agricultural activities, determines water circulation [43]. Therefore, in order to improve the antidrought capacity, proper agronomy practices must be adopted, which is critical to maintain a high level of PSE. In this study, RFM significantly improved nongrowing season PSE, compared with the conventional treatment without mulching. The average nongrowing season PSE of the film mulching treatments (M1N0, M1N1) was about 78\%, while the average PSE of the non-mulching treatments (M0N0, M0N1) was $17.7 \%$ (Table 4). The nongrowing season PSE of mulched treatment in this study was even higher than the value of the PSE in the no-tilled field [44].

A higher PSE indicates that more precipitation would be harvested in the soil and used for maize growth. In our study, we found there was a significant positive relationship between the total nongrowing season precipitation and the PSE of the treatments without mulching (M0N0, M0N1), while the relationship between the total nongrowing season precipitation and PSE in the treatments with mulching (M1N0, M1N1) was not significant (Figure 7). Moreover, it should be noted that the $\mathrm{N}$ fertilizer also reduced the annual variation in the PSE when compared to the M1N0 and M1N1 treatments. A high and stable PSE is meaningful to rainfed agriculture in the Loess Plateau region, especially against the background of climate change under which extreme and uneven precipitation may occur more often.

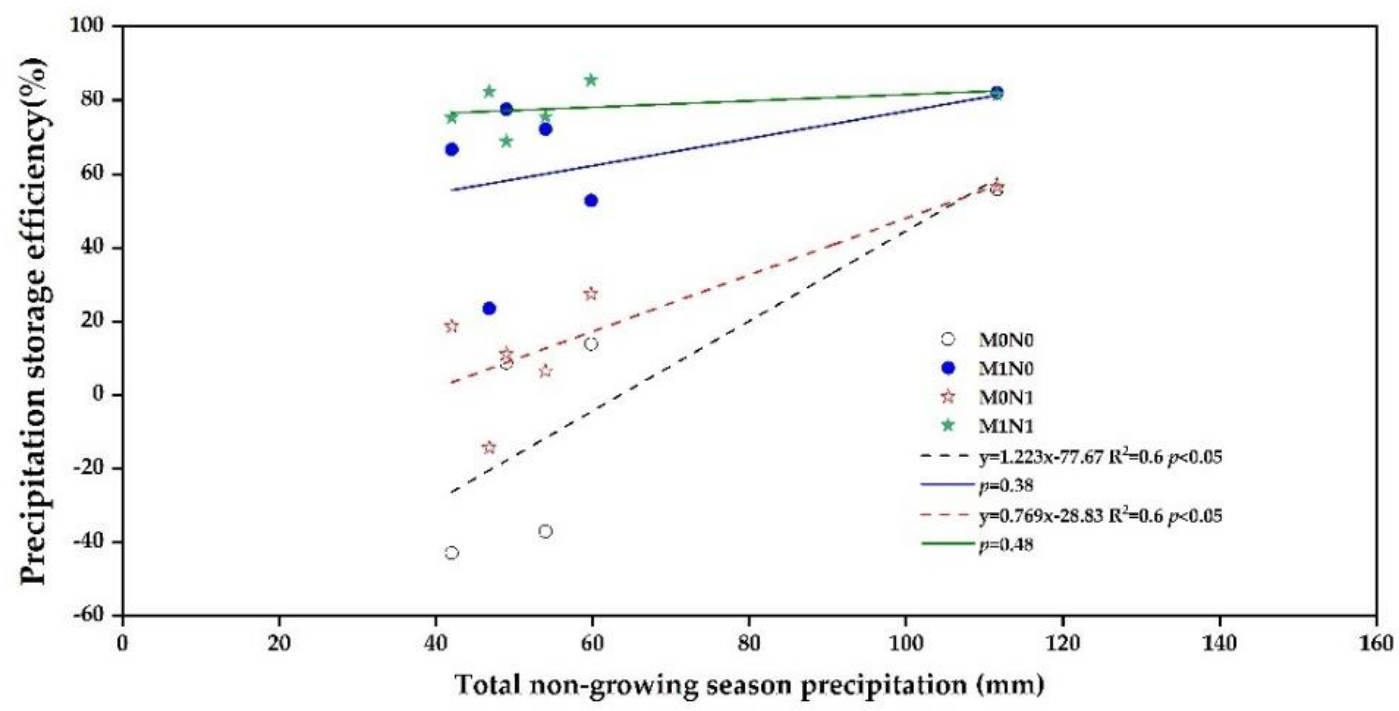

Figure 7. Linear relationship between precipitation and precipitation storage efficiency in the nongrowing season.

There was no doubt that the amount of precipitation affected PSE and the soil water balance. Another important factor which should not be ignored is the rainfall distribution. Different distributions of precipitation may lead to different results, which needs to be further studied.

\subsection{Plastic Film Residue of RFM System}

According to the China Agricultural Statistical Yearbook, in the past three decades, the volume of plastic film used in China has increased nearly fourfold, with an annual growth rate of 7.1\% [45]. Most plastic films used in the RFM system are not biologically degradable at present. The biggest 
challenge of RFM is the low rate of film recovery. Large amounts of plastic film residue can cause serious agricultural problems [46]. Plastic film residue can affect moisture and nutrient transportation, crop emergence and root growth, secondary salinization of soil, and soil health [45]. Effective methods have been put forward to solve the problem of plastic film residue. The first is to produce thicker plastic film, more than the $0.008 \mathrm{~mm}$ film that is used in China, to increase the rate of film recovery [47]. The second is to accelerate the development of biodegradable film, which is friendly to the soil environment [48]. In the area where our study was conducted, the government have paid much attention to the recovery of plastic film residue, and we expect that biodegradable film will rapidly develop and be adopted in the RFM system.

\section{Conclusions}

Through a seven-year maize field experiment, we studied the effects of the ridge-furrow system with full plastic film mulching cultivation on maize grain yield and soil water dynamics. On the basis of these two indicators, we tried to make an assessment on the sustainability of the RFM system. Our experimental results demonstrate that the combination of plastic film mulch and nitrogen fertilization increased the sustainability yield index, which means that RFM cultivation could maintain higher crop yields in the long term. Meanwhile, the RFM system did not overuse the soil water resources and did not lead to soil desiccation layers. The water consumption and recharge were balanced. Especially, the higher PSE in the nongrowing season induced significantly higher soil water content, which was important in crop emergence in the following sowing period. We highlighted the vital influence of the higher PSE brought about by the RFM system, and the key role of a high PSE in the nongrowing season in the success of the ridge-furrow with full plastic film mulching system.

There is no denying that the sustainability of the RFM system in semiarid agriculture is also determined by many other factors, such as soil organic carbon [18], soil nutrients [19], and so on. However, from the view of crop yield and water balance, we demonstrated that the RFM system is sustainable in rainfed agriculture.

Author Contributions: Conceptualization, M.L. and F.Z.; methodology, M.L.; investigation, M.L. and K.Z. and I.M.E.; resources, F.Z. and Y.F.; writing-original draft preparation, M.L.; writing-review and editing, F.Z.; supervision, F.Z.; project administration, F.Z.; funding acquisition, F.Z. All authors have read and agreed to the published version of the manuscript.

Funding: This work was funded by the National Natural Science Foundation of China (grant No. 31770480, 41671017), the Foundation of Key Laboratory of High Water Utilization on Dryland of Gansu Province (grant No. HNSJJ-2019-06), and the Fundamental Research Funds for the Central Universities (grant No. lzujbky-2018-101).

Conflicts of Interest: The authors declare no conflict of interest.

\section{References}

1. Zhang, F.; Zhang, W.; Qi, J.; Li, F.-M. A regional evaluation of plastic film mulching for improving crop yields on the Loess Plateau of China. Agric. For. Meteorol. 2018, 248, 458-468. [CrossRef]

2. Wang, Y.P.; Li, X.G.; Zhu, J.; Fan, C.Y.; Kong, X.J.; Turner, N.C.; Siddique, K.H.M.; Li, F.-M. Multi-Site assessment of the effects of plastic-Film mulch on dryland maize productivity in semiarid areas in China. Agric. For. Meteorol. 2016, 220, 160-169. [CrossRef]

3. Liu, C.A.; Jin, S.L.; Zhou, L.M.; Jia, Y.; Li, F.M.; Xiong, Y.C.; Li, X.G. Effects of plastic film mulch and tillage on maize productivity and soil parameters. Eur. J. Agron. 2009, 31, 241-249. [CrossRef]

4. Piao, S.; Ciais, P.; Huang, Y.; Shen, Z.; Peng, S.; Li, J.; Zhou, L.; Liu, H.; Ma, Y.; Ding, Y.; et al. The impacts of climate change on water resources and agriculture in China. Nature 2010, 467, 43-51. [CrossRef]

5. Gan, Y.; Siddique, K.H.M.; Turner, N.C.; Li, X.-G.; Niu, J.-Y.; Yang, C.; Liu, L.; Chai, Q. Ridge-Furrow Mulching Systems-An Innovative Technique for Boosting Crop Productivity in Semiarid Rain-Fed Environments. Adv. Agron. 2013, 118, 429-476. [CrossRef] 
6. Li, R.; Hou, X.; Jia, Z.; Han, Q.; Ren, X.; Yang, B. Effects on soil temperature, moisture, and maize yield of cultivation with ridge and furrow mulching in the rainfed area of the Loess Plateau, China. Agric. Water Manag. 2013, 116, 101-109. [CrossRef]

7. Zhou, L.-M.; Li, F.-M.; Jin, S.-L.; Song, Y. How two ridges and the furrow mulched with plastic film affect soil water, soil temperature and yield of maize on the semiarid Loess Plateau of China. Field Crop. Res. 2009, 113, 41-47. [CrossRef]

8. Liu, C.-A.; Zhou, L.-M.; Jia, J.-J.; Wang, L.-J.; Si, J.-T.; Li, X.; Pan, C.-C.; Siddique, K.H.M.; Li, F.-M. Maize yield and water balance is affected by nitrogen application in a film-mulching ridge-furrow system in a semiarid region of China. Eur. J. Agron. 2014, 52, 103-111. [CrossRef]

9. Chen, Y.; Liu, T.; Tian, X.; Wang, X.; Li, M.; Wang, S.; Wang, Z. Effects of plastic film combined with straw mulch on grain yield and water use efficiency of winter wheat in Loess Plateau. Field Crop. Res. 2015, 172, 53-58. [CrossRef]

10. Zhang, S.; Sadras, V.; Chen, X.; Zhang, F. Water use efficiency of dryland maize in the Loess Plateau of China in response to crop management. Field Crop. Res. 2014, 163, 55-63. [CrossRef]

11. Ali, S.; Jan, A.; Zhang, P.; Khan, M.N.; Cai, T.; Wei, T.; Ren, X.; Jia, Q.; Han, Q.; Jia, Z. Effects of ridge-Covering mulches on soil water storage and maize production under simulated rainfall in semiarid regions of China. Agric. Water Manag. 2016, 178, 1-11. [CrossRef]

12. Wu, Y.; Huang, F.; Jia, Z.; Ren, X.; Cai, T. Response of soil water, temperature, and maize (Zea may L.) production to different plastic film mulching patterns in semi-Arid areas of northwest China. Soil Tillage Res. 2017, 166, 113-121. [CrossRef]

13. Zhang, H.; Liu, Q.; Yu, X.; Lü, G.; Wu, Y. Effects of plastic mulch duration on nitrogen mineralization and leaching in peanut (Arachis hypogaea) cultivated land in the Yimeng Mountainous Area, China. Agric. Ecosyst. Environ. 2012, 158, 164-171. [CrossRef]

14. Dong, Q.G.; Yang, Y.; Yu, K.; Feng, H. Effects of straw mulching and plastic film mulching on improving soil organic carbon and nitrogen fractions, crop yield and water use efficiency in the Loess Plateau, China. Agric. Water Manag. 2018, 201, 133-143. [CrossRef]

15. Jiang, R.; Li, X.; Zhu, W.; Wang, K.; Guo, S.; Misselbrook, T.; Hatano, R. Effects of the ridge mulched system on soil water and inorganic nitrogen distribution in the Loess Plateau of China. Agric Water Manag. 2018, 203, 277-288. [CrossRef] [PubMed]

16. Han, X.; Hu, C.; Chen, Y.; Qiao, Y.; Liu, D.; Fan, J.; Li, S.; Zhang, Z. Crop yield stability and sustainability in a rice-wheat cropping system based on 34-Year field experiment. Eur. J. Agron. 2020, 113. [CrossRef]

17. Hu, C.; Li, S.L.; Qiao, Y.; Liu, D.H.; Chen, Y.F. Effects of 30 years repeated fertilizer applications on soil properties, microbes and crop yields in rice-wheat cropping systems. Exp. Agric. 2015, 51, 355-369. [CrossRef]

18. Manna, M.C.; Swarup, A.; Wanjari, R.H.; Ravankar, H.N.; Mishra, B.; Saha, M.N.; Singh, Y.V.; Sahi, D.K.; Sarap, P.A. Long-Term effect of fertilizer and manure application on soil organic carbon storage, soil quality and yield sustainability under sub-humid and semi-arid tropical India. Field Crop. Res. 2005, 93, 264-280. [CrossRef]

19. Reddy, D.; Rao, A.; Reddy, K.; Takkar, N. Yield sustainability and phosphorus utilization in soybean-Wheat system on Vertisols in response to integrated use of manure and fertilizer phosphorus. Field Crop. Res. 1999, 62, 181-190. [CrossRef]

20. Cai, A.; Zhang, W.; Xu, M.; Wang, B.; Wen, S.; Shah, S.A.A. Soil fertility and crop yield after manure addition to acidic soils in South China. Nutr. Cycl. Agroecosyst. 2018, 111, 61-72. [CrossRef]

21. Li, C.-X.; Ma, S.-C.; Shao, Y.; Ma, S.-T.; Ling-ling, Z. Effects of long-Term organic fertilization on soil microbiologic characteristics, yield and sustainable production of winter wheat. Agric. Sci. China 2018, 17, 210-219. [CrossRef]

22. Zhou, L.-M.; Zhang, F.; Liu, C.-A. Improved yield by harvesting water with ridges and subgrooves using buried and surface plastic mulchs in a semiarid area of China. Soil Tillage Res. 2015, 150, 21-29. [CrossRef]

23. Bu, L.-D.; Liu, J.-L.; Zhu, L.; Luo, S.-S.; Chen, X.-P.; Li, S.-Q.; Lee Hill, R.; Zhao, Y. The effects of mulching on maize growth, yield and water use in a semi-Arid region. Agric. Water Manag. 2013, 123, 71-78. [CrossRef]

24. Xie, Z.-K.; Wang, Y.-J.; Li, F.-M. Effect of plastic mulching on soil water use and spring wheat yield in arid region of northwest China. Agric. Water Manag. 2005, 75, 71-83. [CrossRef] 
25. Sun, M.; Ren, A.-X.; Gao, Z.-Q.; Wang, P.-R.; Mo, F.; Xue, L.-Z.; Lei, M.-M. Long-Term evaluation of tillage methods in fallow season for soil water storage, wheat yield and water use efficiency in semiarid southeast of the Loess Plateau. Field Crop. Res. 2018, 218, 24-32. [CrossRef]

26. Jiang, X.; Li, X.G. Assessing the effects of plastic film fully mulched ridge-Furrow on rainwater distribution in soil using dye tracer and simulated rainfall. Soil Tillage Res. 2015, 152, 67-73. [CrossRef]

27. Chen, H.; Shao, M.; Li, Y. Soil desiccation in the Loess Plateau of China. Geoderma 2008, 143, 91-100. [CrossRef]

28. Li, S.X.; Wang, Z.H.; Li, S.Q.; Gao, Y.J.; Tian, X.H. Effect of plastic sheet mulch, wheat straw mulch, and maize growth on water loss by evaporation in dryland areas of China. Agric. Water Manag. 2013, 116, 39-49. [CrossRef]

29. Jia, H.; Zhang, Y.; Tian, S.; Emon, R.M.; Yang, X.; Yan, H.; Wu, T.; Lu, W.; Siddique, K.H.M.; Han, T. Reserving winter snow for the relief of spring drought by film mulching in northeast China. Field Crop. Res. 2017, 209, 58-64. [CrossRef]

30. Farahani, H.; Peterson, G.; Westfall, D. Dryland Cropping Intensification: A Fundamental Solution to Efficient Use of Precipitation. Adv. Agron. 1998, 64, 197-223. [CrossRef]

31. Wang, L.; Li, X.G.; Guan, Z.-H.; Jia, B.; Turner, N.C.; Li, F.-M. The effects of plastic-Film mulch on the grain yield and root biomass of maize vary with cultivar in a cold semiarid environment. Field Crop. Res. 2018, 216, 89-99. [CrossRef]

32. Wang, X.; Li, Z.; Xing, Y. Effects of mulching and nitrogen on soil temperature, water content, nitrate-N content and maize yield in the Loess Plateau of China. Agric. Water Manag. 2015, 161, 53-64. [CrossRef]

33. Liu, Q.; Chen, Y.; Liu, Y.; Wen, X.; Liao, Y. Coupling effects of plastic film mulching and urea types on water use efficiency and grain yield of maize in the Loess Plateau, China. Soil Tillage Res. 2016, 157, 1-10. [CrossRef]

34. Eldoma, I.M.; Li, M.; Zhang, F.; Li, F.-M. Alternate or equal ridge-Furrow pattern: Which is better for maize production in the rain-fed semi-arid Loess Plateau of China? Field Crop. Res. 2016, 191, 131-138. [CrossRef]

35. Mo, F.; Wang, J.Y.; Li, F.M.; Nguluu, S.N.; Ren, H.X.; Zhou, H.; Zhang, J.; Kariuki, C.W.; Gicheru, P.; Kavagi, L.; et al. Yield-Phenology relations and water use efficiency of maize (Zea mays L.) in ridge-furrow mulching system in semiarid east African Plateau. Sci. Rep. 2017, 7, 3260. [CrossRef] [PubMed]

36. Wang, S.; Wang, H.; Zhang, Y.; Wang, R.; Zhang, Y.; Xu, Z.; Jia, G.; Wang, X.; Li, J. The influence of rotational tillage on soil water storage, water use efficiency and maize yield in semi-arid areas under varied rainfall conditions. Agric. Water Manag. 2018, 203, 376-384. [CrossRef]

37. Li, Z.F.; Xu, M.-G.; Zhang, H.M.; Zhang, S.X.; Zhang, W. Sustainability of crop yields in China under long-Term fertilization and different ecological conditions. Ying Yong Sheng Tai Xue Bao 2010, 21, 1264-1269.

38. Liu, Y.; Yang, S.; Li, S.; Chen, X.; Chen, F. Growth and development of maize (Zea mays L.) in response to different field water management practices: Resource capture and use efficiency. Agric. For. Meteorol. 2010, 150, 606-613. [CrossRef]

39. Nielsen, D.C.; Vigil, M.F. Precipitation Storage Efficiency during Fallow in Wheat-Fallow Systems. Agron. J. 2010, 102. [CrossRef]

40. Alletto, L.; Coquet, Y.; Justes, E. Effects of tillage and fallow period management on soil physical behaviour and maize development. Agric. Water Manag. 2011, 102, 74-85. [CrossRef]

41. Grassini, P.; You, J.; Hubbard, K.G.; Cassman, K.G. Soil water recharge in a semi-arid temperate climate of the Central U.S. Great Plains. Agric. Water Manag. 2010, 97, 1063-1069. [CrossRef]

42. Zhang, Z.; Zhang, Y.; Sun, Z.; Zheng, J.; Liu, E.; Feng, L.; Feng, C.; Si, P.; Bai, W.; Cai, Q.; et al. Plastic film cover during the fallow season preceding sowing increases yield and water use efficiency of rain-Fed spring maize in a semi-arid climate. Agric. Water Manag. 2019, 212, 203-210. [CrossRef]

43. Gomiero, T.; Pimentel, D.; Paoletti, M.G. Environmental Impact of Different Agricultural Management Practices: Conventional vs. Organic Agriculture. Crit. Rev. Plant Sci. 2011, 30, 95-124. [CrossRef]

44. Nielsen, D.C. Crop Residue and Soil Water. 2006. Available online: https://www.researchgate.net/publication/ 228766201_Crop_residue_and_soil_water (accessed on 22 April 2020).

45. Liu, E.K.; He, W.Q.; Yan, C.R. 'White revolution' to 'white pollution'-Agricultural plastic film mulch in China. Environ. Res. Lett. 2014, 9, 091001. [CrossRef]

46. Chang, R.P.; Yan, C.Y. Research Report on Overall Current Situation on Agricultural Plastics Residuals Pollution and Its Countermeasures; Agricultural Science and Technology Press: Beijing, China, 2012. 
47. Chen, Y.W.C.; Zhang, H.; Lin, Q.; Hong, Y.; Luo, Y. Empirical estimation of pollution load and contamination levels of phthalate esters in agricultural soils from plastic film mulching in China Environment. Earth Sci. 2013, 70, 239-247. [CrossRef]

48. Kyrikou, I. Biodegradation of agricultural plastic films: A critical review. J. Polym. Environ. 2007, 15, 125-150. [CrossRef] 